IRSH 64 (2019), pp. 389-4I 4 doi:I0.1017/So0208590 I900053 I

(C) 2019 Internationaal Instituut voor Sociale Geschiedenis

\title{
Counter-Theatre during the 1797 Fleet Mutinies*
}

\author{
CALLUM EASTON \\ University of Cambridge, Trinity College \\ Cambridge, CB2 ITQ
}

E-mail: ce309@cam.ac.uk

AвSTRACT: In the spring of I797, when French invasion appeared likely, the Spithead and Nore mutinies successively immobilized the two Royal Navy fleets responsible for home defence. The Spithead mutineers gained more pay and greater food rations for all Royal Navy sailors, and a general pardon for themselves. The Nore mutiny ended in collapse, courts martial, and the execution of approximately twenty-eight prominent mutineers. In their scale and potential danger, these fleet mutinies rank among the most serious manifestations of collective resistance in eighteenth-century Britain. In complexity, they far exceeded single-ship mutinies like the Bounty or Hermione. The mutineers deliberately subverted symbols of the legitimate rule of officers and deployed them in support of their own rival regime. "Counter-theatre" allowed the mutineer leaders to perpetuate their rule with minimal recourse to coercion by combining familiar symbols of naval order, new mutineer power structures, and sailors' traditions of resistance. As such, the mutinies speak to wider literatures: to histories of the age of revolutions, to the revolutionary Atlantic, and to histories of popular protest and resistance.

When the frigate Prompte arrived at Spithead from the Caribbean in summer I797, its crew were unaware of the mutinies at Spithead and the Nore, which had lately paralyzed two British fleets. As usual when entering a friendly port,

\footnotetext{
* I would like to thank Dr Renaud Morieux and Dr Quintin Colville for their patient and generous advice in the preparation of this article. I am also very grateful to Dr Elin Jones for allowing me to read her Ph.D. thesis prior to its publication. The research for this article was completed as part of an AHRC-funded collaborative doctoral project entitled "The I 797 naval mutinies at Spithead and the Nore" based at the University of Cambridge and the National Maritime Museum, Greenwich. It is a pleasure to extend my thanks to the National Maritime Museum for the use of several images from their tremendous collections.
}

Abbreviations:

NMM The National Maritime Museum, Greenwich

TNA The National Archives, Kew

CMPNM Court Martial Papers Nore Mutiny

CMP Court Martial Papers 
the sailors assembled to give three cheers for the local flagship. Before these cheers could be given, however, a lieutenant in a nearby boat shouted that "You are not to cheer at all", as "there has been too much cheering already". The cause of this excessive cheering was the practice, shared by the mutineers at Spithead and the Nore, of starting and ending each day with three cheers as a sign that all was well. Cheering was an established naval tradition: a means of instilling loyalty and shared identity in a ship's company. Captain Bligh, of Bounty fame, for example, recorded in his log for the Director that on 6 March 1797 he "cheered ship on receiving the intelligence of Sir John Jervis' victory over the Spaniards". ${ }^{2}$ The act of cheering was, therefore, associated with victory, loyalty, and duty. The Spithead and Nore mutineers deliberately appropriated this element of naval custom and repurposed it to serve as a reaffirming symbol of their own control and unity. This was just one of many examples of the conscious adaptation of well-established naval conventions to serve mutineer ends during the 1797 fleet mutinies. At the same time, the mutineers supplemented these familiar naval symbols with structures and practices of their own. The result was a hybrid system through which the mutineers combined the appropriation of symbols of naval order with the creation of their own hierarchies and structures of authority. The interface between these actions: contrasting in style but mutually supporting in practice, are the subject of this article.

While the standard work on the 1797 fleet mutinies remains Conrad Gill's I9I 3 book, the most recent contribution, edited by Ann Coats and Philip MacDougall, effectively challenged persistent myths of the mutinies, such as the claim that they were failed revolutions instigated by seditious groups like the London Corresponding Society (LCS) or United Irishmen (UI). ${ }^{3}$ Coats calculated that Irish-born sailors composed, on average, approximately one quarter of the crews at Spithead, with the majority long-established naval sailors. Among the mutineer leaders, the proportion was just four Irish out of thirty-three. No correlation was found between the proportion of a crew that was Irish and revolutionary activity. ${ }^{4}$ Instead, the chief mutineers were overwhelmingly drawn from the most skilled and experienced sailors. Of the thirty-three Spithead Delegates, ${ }^{5}$ twenty were petty officers and thirteen were able seamen. They had been on board their ships for between two and four years. At the Nore, the mutineer leaders of the Director were seven

I. James Dugan, The Great Mutiny (London, 1966), p. 323.

2. Captain's Log, HMS Director, Monday 6 March 1797, TNA ADM5i/r 195.

3. Conrad Gill, The Naval Mutinies of 1797 (Manchester, I913); Ann Veronica Coats and Philip MacDougall (eds.), The Naval Mutinies of I797: Unity and Perseverance (Woodbridge, 20I I).

4. Coats and MacDougall, The Naval Mutinies of I797, pp. 3, I 33, I 37.

5 . The name of members of the leading mutineer committee and a term charged with connotations of illicit societies like the LCS. 
petty officers, a skilled seaman, a marine NCO, and a marine private. ${ }^{6}$ This suggests that, contrary to suggestions by some contemporaries and histories, newly enrolled agitators did not exercise a leading role in the mutinies. ${ }^{7}$

Markus Rediker and Peter Linebaugh have presented the "rough, improvised, but effective egalitarianism" that characterized life on the lower decks as sailors organized to regulate the terms of their "semi-unfree labour". Their cosmopolitan and internationally mobile ranks, united by professional solidarities, developed a complex oppositional culture, or "hydrarchy", with which to resist violations of their traditional terms of service. ${ }^{9}$ Rediker emphasized the sailors' ability to devise "various tactics of resistance and forms of self-organization". In larger disturbances, these tactics saw sailors "expropriate the workplace and arrange it anew". ${ }^{\circ}$ This article examines some of the nuances and complexities of these strategies using the case study of the I797 Royal Navy mutinies at Spithead and the Nore. In particular, attention is drawn to the complementary interface between the mutineer usurpation of familiar symbols of officers' authority and autonomous traditions of sailors' resistance: enduring echoes of Rediker's hydrarchy.

Niklas Frykman has highlighted that an unprecedented concentration of mutinies struck European navies in the I 790 os and has called this transnational phenomenon the "mutinous Atlantic". ${ }^{11}$ Concentrating on a comparison between mutinies in the Dutch, French, and British navies, Frykman highlighted commonalities, such as their simultaneity and focus on conditions of service. Nevertheless, Frykman recognized the peculiarity of the British case, where some of the largest and most disciplined instances of mutiny took place, but where they had a negligible impact on the course of the French Revolutionary Wars compared to their French and Dutch counterparts. ${ }^{\text {I2 }}$

Much of this difference was the result of divergent contexts. In his study of unrest in the French Revolutionary navy, William Cormack emphasized a fluid conflict between competing authorities as royal executive power was replaced

6. Coats and MacDougall, The Naval Mutinies of I797, p. 4I; NMM ADM/L/D/r29, Log of J. Griffiths, Lieutenant of HMS Director, May to June 1797 .

7. For contemporary opinions and later histories that blamed outside agents for inciting sailors to mutiny, see the Report of the Committee of Secrecy of the House of Commons (Dublin, 1799); Roger Wells, Insurrection: The British Experience, I795-I 803 (Gloucester, I986), pp. 93-94.

8. Markus Rediker, Villains of All Nations: Atlantic Pirates in the Golden Age (London, 2012), p. 6I; Peter Linebaugh and Markus Rediker, The Many-Headed Hydra: Sailors, Slaves, Commoners, and the Hidden History of the Revolutionary Atlantic (London, 2000), pp. 143-44. 9. Linebaugh and Rediker, The Many-Headed Hydra, pp. I I, I 5 8-1 59.

I0. Markus Rediker, Between the Devil and the Deep Blue Sea: Merchant Seamen, Pirates, and the Anglo-American Maritime World, I700-1750 (Cambridge, 1987), pp. 7, 77-78, 106.

I I. Niklas Frykman, "Connections between Mutinies in European Navies", International Review of Social History, 58:S2I (2013), pp. 87-107.

I 2. Ibid., pp. 93-94. 
by popular sovereignty. This involved the replacement of the legitimising symbols and rituals of one system of order with those of another: for example, the royal ensign gave way to the tricolour. Similar conflicts also affected the Batavian navy, which suffered a wave of mass desertions, with sailors sometimes destroying their ships as they left. ${ }^{13}$ This context, however, was quite different to that at Spithead and the Nore. There, the symbols of order were appropriated and repurposed but not altogether replaced as their fundamental legitimacy, stemming from King and Parliament, was not questioned. ${ }^{14}$ The I 797 British fleet mutinies concentrated on conditions of service, whereas sailors on Batavian ships were more likely to desert, sometimes with their ships. ${ }^{\text {Is }}$ While the allegiance of French and Dutch sailors had changed, that of British sailors remained the same; their temporary regime was a means to appeal to the state for redress over the heads of their immediate naval superiors.

Though Spithead and the Nore are seen as a climax of the I790s wave of mutinies, they were also the origin of their own wave of mutinies. ${ }^{16}$ From there, mutinies spread to the Mediterranean, the Caribbean, the Cape of Good Hope, and into the Indian Ocean. Sailors in these cases often knew about the mutinies at Spithead and the Nore before their officers, highlighting the effectiveness and reach of lower-deck communication and organization networks. Though these outbreaks shared similarities, they also took on a local flavour. Nicole Ulrich has shown that the mutinies at the Cape were a combination of autonomous sailors' traditions of resistance and the local context of disputed labour relations. Sailors began to look beyond expressions of the rights of "freeborn Englishmen" and, in turn, inspired later protests at the Cape. ${ }^{17}$ This demonstrates the need to study sailors' actions in a context wider than that of their own ship: a prescient point also for Spithead and the Nore. In that case, however, though the naval crews were thoroughly international, their actions and rhetoric remained closely connected to ideas of traditional rights. ${ }^{18}$ As such, the mutinies deserve a prominent position in histories of the age of revolutions, of the revolutionary Atlantic, and of popular protest

I3. Niklas Frykman, "The Wooden World Turned Upside Down" (Ph.D., University of Pittsburgh, 2010), p. I60.

I4. William S. Cormack, Revolution and Political Conflict in the French Navy 1789-94 (Cambridge, 1995), pp. 56-58, 77, 300.

I 5. Frykman, “The Wooden World Turned Upside Down”, p.206.

16. Though the spike in mutiny trials was partly caused by nervous officers charging men for offences that, before the fleet mutinies, would likely have escaped trial. ADM I 2/24, Analysis and Digest of Court Martial Convictions, Arranged by Offence: J-N, I755-1806.

17. Sara Caputo, "Alien Seamen in the British Navy, British Law, and the British State, c.1793c.I 8 I 5", The Historical Journal, I0/2/2018, pp. I-23; Nicole Ulrich, "International Radicalism, Local Solidarities: The 1797 British Naval Mutinies in Southern African Waters", International Review of Social History, 58:S2 I (20I3), pp. 6I-85, 7I-73, 77, 84-85.

I 8. Ibid., pp. 78-8I; E.P. Thompson, "The Moral Economy of the English Crowd in the Eighteenth Century", Past and Present, 50 (1971), pp. I IO-I I 2,I35. 
and resistance. At Spithead and the Nore terrestrial trends, such as moral economy and counter-theatre, met the global phenomenon of maritime radicalism. The result was a complex and effective structure of order that drew freely on both traditions.

Despite this growing corpus of work, important questions remain about the ways in which the mutinous seamen were able to maintain unity of purpose and action. There was not unanimity; the mutinous fleets were home to many different sentiments, some of which were, from first to last, hostile to the mutiny. Nevertheless, the presence of factions with diverse and sometimes diametrically antagonistic views makes it even more surprising that the mutineers were able to maintain cohesion to the extent and for the duration that they did. Consequently, no understanding of the fleet mutinies of 1797 can be complete without addressing the practical measures taken by the leading mutineers to encourage compliance, tacit though it might have been, and to extend the lifespan of their new regime.

Steven Pfaff, Michael Hechter, and Katie Corcoran used a quantitative sociological approach to argue that coercion was the crucial factor in explaining the duration of the Nore mutiny. Mutineer leaders controlled the spread of information, monitored opponents, and issued "credible threats" of punishment. While this study offers new perspectives on the mutiny, it is argued here that their conclusion that "sometimes ideology or the bonds of community can attain the requisite compliance, but not at the Nore" assigns too little significance to social and community factors on board Royal Navy warships. ${ }^{19}$ Social and community factors had a significant impact on the actions of mutinous sailors and made it possible to prolong the mutinies. In particular, the leading mutineers were able to assert the legitimacy of their enterprise through the usurpation and adaptation of rituals and symbols associated with authority in combination with their own power structures. They thereby presented their cause as just and laid claim to obedience and loyalty. This is not to deny that coercive elements were present during the fleet mutinies; they undoubtedly were. Instead, it should be emphasized that these formed just one strand of a broader and more nuanced strategy to foster unity.

In several respects, the appropriation and adaptation of symbols and rituals of naval order by the mutinous sailors was consistent with the "countertheatre" identified by John Brewer as a common element of collective protest on shore. Counter-theatre involved the appropriation of symbols and rituals associated with one particular message or meaning, and their subversion and application to another. These acts were considered especially impudent and

19. Steven Pfaff, Michael Hechter, and Katie E. Corcoran, "The Problem of Solidarity in Insurgent Collective Action: The Nore Mutiny of 1797", Social Science History, 40 (2016), pp. $247-270,267$. 
worthy of severe punishment. ${ }^{20}$ Through devices like the Riot Act, the British state made some provision for legitimate protest and this was also true of the navy, ${ }^{2 \mathrm{I}}$ but mutiny and inversion of symbols of order were beyond the pale. Theoretically, a sailor who ignored a command to scrub the decks would be guilty of simple disobedience because he defied the system of order on board. If that sailor were to force an officer to scrub the decks, this would be counter-theatre because it represents a public inversion of social norms in support of a rival system of order. ${ }^{22}$ The level of attention devoted to such inversions in courts martial and naval officers' accounts reveals the concern of the naval authorities. ${ }^{23}$ There were legitimate grounds to fear that the mutineer usurpation of authoritative symbols undermined the rituals on which naval officers rested their day to day rule by consent. ${ }^{24}$

The transcripts of the courts martial that followed the Nore mutiny provide an excellent source for a detailed study of mutineer counter-theatre. The words spoken by each individual were carefully recorded, and Mr Gurney, the scribe of the House of Commons, was employed for that purpose. ${ }^{25}$ Courts martial where men spoke with their lives in the balance provide imperfect sources, but also the best available for revealing day to day life during the mutinies, as well as a rare opportunity to read the words of ordinary sailors. Crucially, many of the best examples of mutineer appropriation of symbols of order come from the statements, questions, and defences of the mutineers themselves. The officers leading the questioning expended much court time and energy in investigations of counter-theatrical behaviour. It should be noted that, as no trials followed the Spithead mutiny, court martial records are only available for the Nore mutiny. Nevertheless, multiple other sources including personal accounts, captains', masters', and lieutenants' logs allow for easy comparison of the emblematic and theatrical features present at Spithead and the Nore. Due to their notable commonalities of practice in this regard, the instances

20. John Brewer, Party Ideology and Popular Politics at the Accession of George III (Cambridge, I976), pp. I 8 I-I 83 .

2I. There were recognized forms of protest, such as petitioning superior officers, but the mutineers had exhausted these avenues without success.

22. Natalie Zemon Davis found similar behaviour among religious rioters in sixteenth-century France, who occupied churches in support of their cause. Natalie Zemon Davis, Society and Culture in Early Modern France (London, 1975), pp. I6I-I63.

23. For Nore courts martial see, for example, CMPNM TNA ADMr $/ 5486 / 4$, p. 7. For officers' accounts of the Spithead mutiny see, for example, NMM COO/2/a, Reflections on the Mutiny at Spithead, 1797: Papers of Sir Edward William Campbell (1825), pp. I-6.

24. The letter from the panel of Nore judges (see footnote 86) can be interpreted as an expression of this concern. Letter from Nore courts martial judges to government law officers, i I July I797, NMM MRK/I00/5/8.

25. Admiralty Correspondence Digests, TNA ADMi2/74, letter references $\mathrm{C}_{4} 69$, I July i797; and Solr, is September 1797. 
of allegorical disobedience observed at these two mutinies will be discussed together throughout this article.

The forms taken by mutineer disobedience are discussed in turn. At each stage their interaction with alternative mutineer practices and power structures will be evaluated in order to convey the complexity of the mutineer regimes, and their propensity to persuasion rather than coercion. Section one briefly describes the trajectory of the 1797 fleet mutinies. In section two, the simultaneous mutineer usurpation of the spaces and roles of officers will be examined. The complex relationship between the two provided legitimising elements of continuity which complemented the newly imposed mutineer hierarchical structures. This usurpation of space and role necessarily involved taking up the practical measures of rule: notably law, order, and administration. Consequently, section three is concerned with the ways in which mutineer rule was constituted and manifested through a hybrid approach that combined the appropriation of symbols of officers' authority with existing sailors' traditions and practices. This will require an analysis of mutineer use of the written word and judicial process. The article will conclude by presenting a direct comparison of the Spithead and Nore mutinies in order to reconcile their marked commonalities of counter-theatrical behaviour to their dramatically different outcomes.

\section{THE I 797 FLEET MUTINIES}

The 1797 fleet mutinies at Spithead and the Nore directly involved approximately 30,000 men, immobilized the two fleets responsible for defending Britain at the height of wartime, and were played out within easy sight of the civilian population on shore. ${ }^{26}$ The presence of the mutinous fleets in the Solent and at the mouth of the Thames struck at the twin pillars of the British "fiscal-naval state": the naval establishment centred on Portsmouth and the maritime trade of London. ${ }^{27}$ The fleet mutinies rank among the largest popular protests in eighteenth-century Britain. By taking control of warships, the mutineers possessed themselves of the most technologically advanced, powerful, and expensive weapons at the disposal of any eighteenth-century state. Order was generally maintained and there was little violence. Because of the inaccessibility of ships, the mutinies became perhaps the longestsustained coherent protest in eighteenth-century Britain as each lasted for a month. As one military observer noted, even "if the whole inhabitants of Britain were soldiers [...] they are unequal to the task of subduing a single 
ship of the line". ${ }^{28}$ Edmund Burke, meanwhile, believed that the mutinies rendered Britain so vulnerable that "our only hope is in a submission to the enemy [...] [on] any terms". ${ }^{29}$

For contemporaries, the mutinies were unprecedented and terrifying, yet they ended relatively peacefully. Short of a coup d'état or defection (which they did not intend), the mutineers knew that the naval authorities would eventually regain control and life would continue much as before. They were also aware that their rhetoric and use of symbols would significantly affect the public perceptions of their cause. This likely encouraged moderation in their demands and behaviour. Correspondingly, the Admiralty appreciated the value of the mutinous men and ships, and so their own actions were shaped by the desire to return to normality with as little delay and ill-feeling as possible.

The mutinies began on I6 April I797, when the sailors of the Channel Fleet refused to sail from Spithead. Six weeks earlier, the discontented sailors had sent petitions for redress of grievances to the veteran Admiral Howe. ${ }^{30}$ Having received no answer, the sailors determined not to put to sea until their demands had been considered. The red flag of defiance was raised, delegates were appointed to speak for each ship, and unpopular officers were confined or sent on shore. Sixteen ships of the line, Britain's first line of defence mounting over I, 300 guns and home to over I I,000 men, refused to budge. Life nevertheless continued in an orderly fashion for four weeks. Daily routines were maintained and the orders of remaining officers were obeyed, apart from weighing anchor. Leading mutineers, such as Valentine Joyce, made it clear that they remained loyal to king and country, but would refuse to leave Spithead until their demands to higher pay, more food, and that of a higher quality, were granted. The mutineers let it be known that they would immediately sail to confront an enemy fleet if one put to sea, and they refused to allow frigates and smaller ships to join the demonstration lest trade should suffer from lack of escorts.

The Lords Commissioners of the Admiralty, led by the First Lord, Earl Spencer, travelled to Portsmouth on I7 April to negotiate with the mutineers and quickly admitted the justice of most of their demands. They conceded higher pay, larger food rations, and pay for sick seamen. Howe also agreed that some unpopular officers would be transferred. Legislation was set in motion and a royal pardon prepared, but, while parliamentary process took its slow course, some mutineers became worried and suspicious. It was at this time, on 7 May, that the only violent incident of the Spithead mutiny

28. Philip Patton, Account of the Mutinies at Spithead and St Helens in April and May 1797, NMM TUN/2 2 pp. 4-5.

29. J.P. Gilson (ed.), Correspondence of Edmund Burke and William Windham (Cambridge, I9I0), p. 24I.

30. Admiralty Petitions c.1793-1798, TNA ADMr/5i25. 
took place. Four mutineers were killed on board the London when Vice Admiral Colpoys attempted to confine sailors below decks. The mutinous crew showed notable restraint and did not take retribution. On is May, the Spithead mutiny ended in cordial celebrations as Admiral Howe informed each ship that their demands had been met. Howe then hosted a lively banquet for the leading mutineers in the spirit of reconciliation, and no one was punished for their involvement in the mutiny.

On I 2 May, shortly before the end of the mutiny at Spithead, a supporting mutiny broke out at the mouth of the Thames. The small, rag-tag Nore fleet was less important to national security than the Channel Fleet and the Admiralty assumed that news of the Spithead settlement would quickly restore order. This was not the case. In form the Nore mutiny was very similar to that at Spithead with the expulsion of officers, the continuation of daily routine, the use of red flags, and the appointment of delegates for each ship. Having just granted most of the demands of one mutinous fleet, the government and Admiralty worried that further concessions would fatally compromise their command. The just grievances of the Spithead fleet had been redressed to the benefit of all sailors. Consequently, a dim view was taken of the Nore mutiny, particularly when new demands were presented. Its figurehead, Richard Parker, did not help matters by acting disrespectfully to his superiors and styling himself "President" of the mutinous fleet.

Determined not to negotiate, and conscious that the small Nore fleet posed little threat, the Admiralty decided to wait out the crisis. ${ }^{3 \mathrm{I}}$ Slowly, the mutiny began to fall apart and several ships abandoned the mutineer cause. On 30 May, however, the bulk of the North Sea Fleet (eleven ships of the line) deserted Admiral Duncan and joined the Nore mutiny. ${ }^{32}$ The authorities cut off supplies to the ships involved, but this backfired when the mutineers blockaded the Thames to confiscate provisions from passing ships. This action decisively turned public opinion against the mutineers and strengthened the government's hand, as expressed in newspapers across the political divide. ${ }^{33}$ The political opposition were torn between a desire to use the mutinies to criticize the government for mismanagement, and the fear of appearing complicit in the dangerous and potentially seditious mutinies. ${ }^{34}$ With no sign of compromise or negotiation, ships again began to defect from the mutiny on 12 June, and the last two ships surrendered three days later. Courts martial

3I. This view was quickly disproved by the mutineers' interdiction of Thames trade.

32. Gill, The Naval Mutinies of 1797 , p. 165.

33. For details on the role of newspapers during the Spithead mutiny see David London, "Mutiny in the Public Eye: The Role of Newspapers in the Spithead Mutiny" (Ph.D., King's College, London, 200I). Government and opposition newspapers were united in their horror at the blockade of the Thames.

34. This unenviable situation receives fuller attention in my Ph.D. thesis, and plays out in sources such as Hansard vol. 33, 3 March I797-30 November 1798 (London, I 8 I 8), pp. 780-820. 
followed and approximately twenty-eight mutineer ringleaders were executed. However, on II October, many of the same ships and crews decisively defeated the Dutch fleet at the battle of Camperdown, which did much to restore the reputation of the navy. ${ }^{35}$ Both mutinies displayed impressive and sustained coordination across a large population of sailors on many ships. Seeking to protect and continue their regime, it is not surprising that the mutineers turned to some of the well-known theatrical rituals that had helped to secure the rule of officers with persistent success. These they combined with traditions and innovations of their own to create a hybrid system. The legitimacy of the old order was wedded to a more egalitarian ethos consistent with maritime conventions of behaviour and resistance.

\section{USURPING THE SPACE AND ROLE OF OFFICERS}

In the cramped confines of eighteenth-century warships, physical space was correlated with power. The captain inhabited his spacious "great cabin", lit by the magnificent stern windows. Commissioned officers had cramped private cabins that opened onto their shared wardroom. They also enjoyed the right to walk the "quarterdeck": simultaneously a physical space and a collective term for the senior men who held that privilege. The humble status of the sailors was also described in spatial terms; they were said to be "before the mast" (quartered forward of the central main mast), and collectively referred to as the "lower decks". For the majority of the crew their only official allocation of space was fourteen inches of width in which to sling their hammock. ${ }^{36}$ Recent work by Elin Jones, however, has done much to emphasize the power of imagined spaces and boundaries among sailors. ${ }^{37}$ The location of many of these shipboard spaces is shown in Figure I.

During the Spithead and Nore mutinies this carefully stratified demarcation of physical space was turned on its head. The mobility of officers was restricted, while mutinous sailors gave orders from the great cabin and quarterdeck. For a sailor to walk on the quarterdeck, unless to perform an essential function, was not merely to trespass; it was to lay claim to a status and legitimate power that were far above his station. Therefore, by issuing orders from that location, the mutineer simultaneously put himself in the physical place of officers and assumed their authoritative role. These appropriations

35. This brief overview of the mutinies presents an uncontroversial narrative that corresponds to the work of, for example, Gill, The Naval Mutinies of I797; and G.E. Manwaring and Bonamy Dobrée, The Floating Republic (London, 1966).

36. In practice this was usually twenty-eight inches as half of the crew would be on duty at any given time. N.A.M. Rodger, The Wooden World: An Anatomy of the Georgian Navy (London, I988), p. 6r.

37. Elin Jones, "Masculinity, Materiality and Space on Board the Royal Navy Ship, 1756-i 8 I 5 " (Ph.D., Queen Mary, University of London, 2016). 


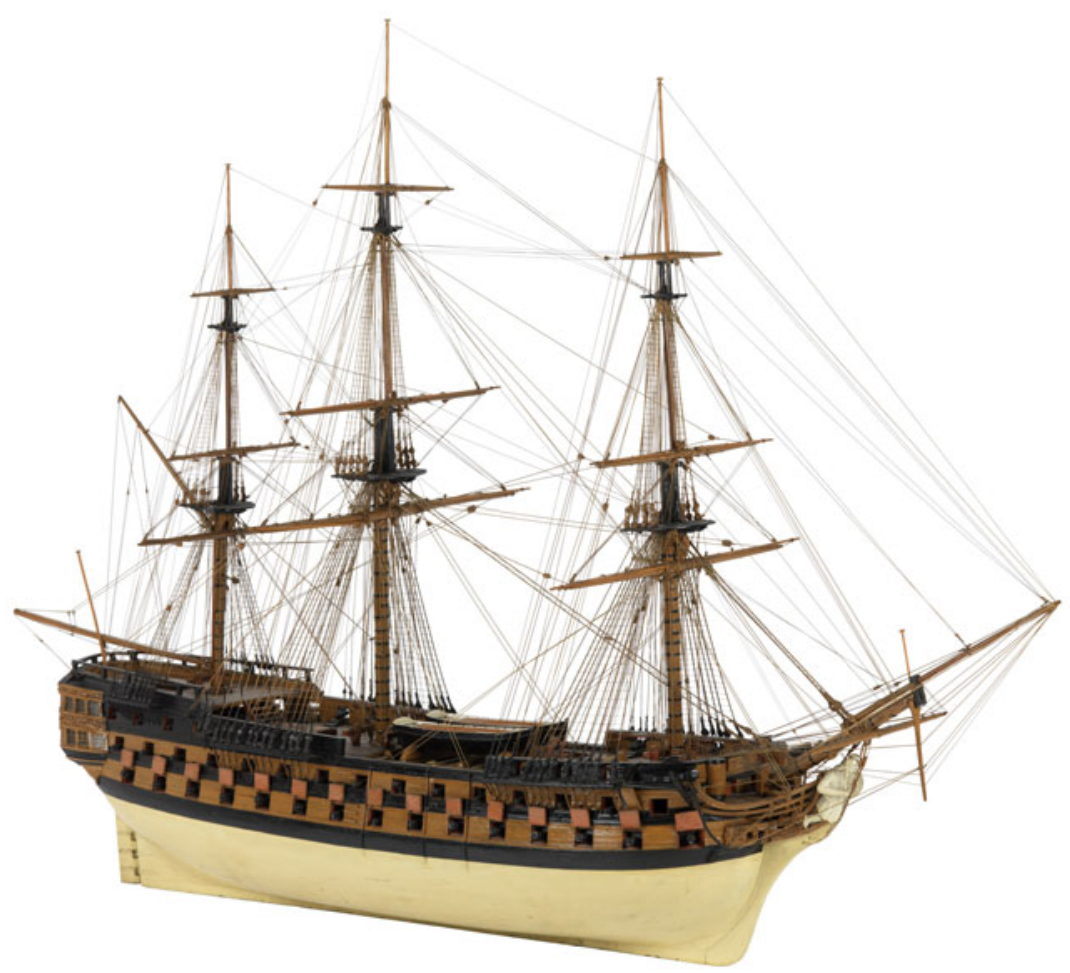

Figure I. This model depicts the third-rate ship of the line HMS Mars, which took part in the Spithead mutiny. Its basic layout is typical of the warships involved in the 1797 fleet mutinies. The quarterdeck is visible between the two rear masts, while the forecastle is the area forward of the ship's boats stowed in the centre of the model. The raised platform aft of the quarterdeck is the poop deck, with the captain's great cabin located directly below it, accessed from the quarterdeck. National Maritime Museum, Greenwich, London, Royal United Service Institution Collection. Object ID: SLRos77.

allowed for continuity of familiar social practice, but in support of a different regime. Such continuity asserted the legitimacy of the mutineer cause and involved an appeal to unity: a theatrical attempt at persuasion rather than coercion.

The association between the quarterdeck and authority was a powerful one, and this was not lost on the prosecutors at the Nore courts martial. When witness John Lapthorne was asked who had commanded Leopard during the mutiny, he responded by naming those sailors who had "walked the quarterdeck". ${ }^{8}$ This link between the occupation of an officer's space and pretentions 
to usurp his jurisdiction was directly explored during the trials. Witness Edward Dawson implicated William Vance of Monmouth for giving orders from the quarterdeck. The court interjected to clarify, "Do you mean to say that he gave those orders in the same manner as the officers were accustomed to when they had the command?". ${ }^{39}$ Similarly, when Joseph Borley related that Thomas Linnes had issued orders throughout the mutiny, the court asked if these had been delivered in the manner "of an officer giving orders proceeding from himself?" $4 \circ$ Vance and Linnes were both sentenced to hang, not least for their temerarious presumption in usurping both the place and role of officers.

At Spithead, too, it was observed that the mutineers administered the ships from the quarterdeck. On board London, for example, mutiny began with an assembly of sailors taking possession of the quarterdeck. ${ }^{4 \mathrm{I}}$ It is important to note that there were practical as well as symbolic advantages to the occupation of the quarterdeck by mutineers. Firstly, as a raised platform towards the rear of the vessel, the quarterdeck had a commanding view of the length of the ship and its environs. ${ }^{42}$ This had obvious advantages for observation and the maintenance of order: both for officers and for the mutineer regime. The same practical advantages, however, were also true of the forecastle, which was much more strongly associated with lower deck culture. ${ }^{43}$ Secondly, the quarterdeck was home to the ship's helm, which cemented that space's status as the centre of command and navigation. The occupation of the quarterdeck by mutineers might therefore be interpreted as a defensive move to protect their own control of the vessel. On the other hand, once involved in the Spithead and Nore mutinies, little movement of ships took place. In the context of mutinies in port, it would be much more important to guard the anchor cables located forward and below decks. These points tend, therefore, to suggest that the practical reasons for occupying the quarterdeck, while important, were not sufficient to explain mutineer behaviour. Furthermore, while there were some practical benefits to the mutineer usurpation of the quarterdeck, the same cannot be said of the captain's cabin, the appropriation of which represented a potent statement, but provided little tangible advantage. As such, the mutineer occupation of spaces of authority appears to have been motivated, at least in part, by symbolic considerations.

To dissect an example in detail, it must be recalled that the significance of the quarterdeck came, at root, from the king. The senior officers held the King's commission and it was on the quarterdeck that they exercised that commission

39. CMPNM TNA ADMi/5486/i9, p. I7.

40. CMPNM TNA ADMi/ $/ 5486 / 3$ I, p. 23 .

4I. NMM COO/2/a, Reflections on the Mutiny at Spithead, I797, p. 2.

42. Jones, "Masculinity, Materiality and Space on Board the Royal Navy Ship, 1756-I815",

pp. 100-104.

43. A raised platform at the front of the ship, of roughly equal height to the quarterdeck. 
by giving orders. The quarterdeck was exalted because it was the place where the King's appointed deputies administered 'His Majesty's Ship'. In practice, however, social convention bred a reverence for the deck itself: a place of honour where few could tread. ${ }^{44}$ The mutineers who gave orders from the quarterdeck did not speak with the voice or sovereignty of the king, but it seems they hoped that their commands would carry more weight thereby. Men like Lapthorne willingly accepted this. Taking possession of the quarterdeck and maintaining its function conveyed clear messages; firstly, the officers' regime had been replaced, secondly, the new order spoke with power and legitimacy just like the old and, thirdly, it had the same expectations of loyalty and obedience.

While possessing themselves of the quarterdeck, the mutineers also maintained the autonomous maritime tradition that cast the forecastle as a rival space to the quarterdeck: a place of congregation and discussion for sailors symmetrical to that of the officers. ${ }^{45}$ Mutiny typically began with an assembly of the crew on the forecastle "in a great body", which then rushed aft to the quarterdeck where mutineers assumed control of the ship. ${ }^{46}$ In some cases, forecastle guns were turned to face the quarterdeck as an added threat to the officers. ${ }^{47}$ The forecastle thereby represented an assertion of the collective strength and identity of the ship's crew: an imperium in imperio for the humble sailors to set against its privileged counterpart. Crucially, the forecastle was a meeting place out of earshot of officers on the quarterdeck; at Spithead, when mutineer delegates arrived on board the London they "were hurried to the forecastle $[\ldots]$ where they might be more free from the restraint the presence of their officers had hitherto imposed on them".$^{8}$

As a meeting place, and as a centre for discussion and resistance, the forecastle fulfilled a similar function to that identified by E.P. Thompson for the marketplace. These were centres of civic pride and identity, of association and discussion. Significantly, they could accommodate large crowds. As Thompson recognized, crowds created a form of anonymity where the individual ceased to be distinguishable from the whole. ${ }^{49}$ The same occurred during the fleet mutinies, which subsequently made life difficult for prosecutors, who struggled to identify ringleaders. Witnesses, such as Thomas Dove, often found it impossible to distinguish individuals among "the general voice" of the

44. Rodger, The Wooden World, pp. 24-25.

45. Jones, "Masculinity, Materiality and Space on Board the Royal Navy Ship, I756-I8I 5 ", p. 103 .

46. CMPNM TNA ADMi/5486/9, pp. 2-3; Captain's Log, HMS Agamemnon, November 1796 to November 1797 , TNA ADM5i/1 i 94 .

47. CMPNM TNA ADMr/5486/9, pp. 2-3; CMPNM TNA ADMr/5486/4, p. 2; Gill, The Naval Mutinies of I797, p. I04; Manwaring and Dobrée, The Floating Republic, p. 32.

48. NMM COO/2/a, Reflections on the Mutiny at Spithead, I797, p. 2.

49. E.P. Thompson, Customs in Common (London, I991), pp. 70-7I. 
ship's crew. ${ }^{50}$ The forecastle proved its worth as a traditional site of seamen's resistance and paralleled patterns of popular protest on shore.

If the forecastle acted like a market square, then the terrestrial equivalent of the quarterdeck was a court bench or church pulpit. It was from there that the captain would address his crew, perform divine service, and read the articles of war (naval law code). These two symmetrical spaces, one forward, the other aft, served different strata of naval society. When mutiny began with a congregation on the forecastle which surged aft to secure the quarterdeck, it was equivalent to a market crowd taking possession of a church, courthouse, or guildhall.

The mutineer appropriation of space extended to the inner sanctum of the captain's cabin. If there were some practical advantages to mutineers of occupying the quarterdeck, the appropriation of the captain's cabin was iconoclastic. The outrage that this inspired in officers is clear from their court testimony. Lieutenant Flatt of Sandwich recalled that mutineer committee meetings were at first held "in the starboard bay and afterwards in the great cabin". ${ }^{\text {I }}$ The ship's surgeon, John Snipe, described with horror his appearance before the committee "then assembled in Captain Mosse's cabin", which Snipe considered "the most daring piece of outrage that I had ever seen in my life". ${ }^{2}$ Most reflective of a sense of the maritime world turned upside down was the testimony of Lieutenant Forbes. When asked if the mutineers moved between the revered places "just as they pleased", Forbes replied "Constantly. Day after day they went from the quarterdeck down the aft ladder into the captain's cabin [...] without any restriction or control". ${ }^{53}$ This practice was common to both the Spithead and Nore mutinies. At the former, the captain's cabin of Queen Charlotte played host to the meetings of the thirty-three delegates of the mutinous fleet, while Sandwich performed the equivalent function of 'parliament ship' at the Nore. ${ }^{54}$ For a contemporary imaginary visualization of such a meeting of delegates, see Figure 2.

Through their usurpation of spaces of authority, the mutineers of Spithead and the Nore simultaneously adopted some of the roles of officers. This can be interpreted as an attempt to encourage unity and obedience on the part of the crew by claiming legitimacy for their cause. Amidst the uncertainties of mutiny, a string of orders issued, as usual, from the quarterdeck and captain's cabin might have represented a comforting and persuasive continuity, which could bind crews together without need for coercion. This inverted continuity would have been all the more important because it was, in several respects, only superficial: a façade blurring the lines between the power structure of

50. CMP TNA ADM/I/5340, HMS Montagu.

5. CMPNM TNA ADMr/5486/9, p. 22.

52. CMPNM TNA ADMi/5486/I, pp. 30, 33 .

53. CMPNM TNA ADMi//5486/ i2, pp. 3 I.

54. Coats and MacDougall, The Naval Mutinies of I797, p. $4 \mathrm{I}$. 


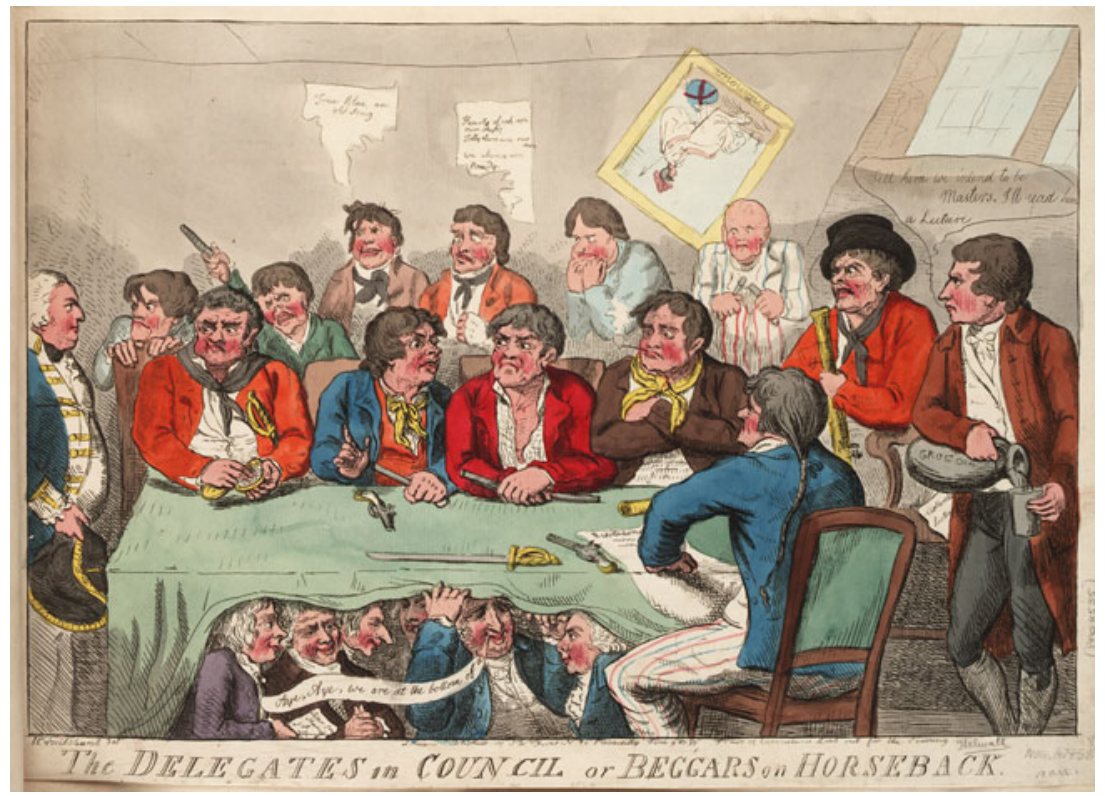

Figure 2. This contemporary caricature by Isaac Cruikshank depicts the hybrid nature of the fleet mutinies, with mutinous sailors combining a usurpation of the space and role of officers with their own egalitarian committee system. The mutineers sit in the great cabin (shown by the stern windows) while a senior officer watches humbled and peripheral. The overall impression is of the naval order (along with Britannia on the rear wall) inverted. The presence of Whig politicians under the table and John Thelwall (far right) of the London Corresponding Society reflects unwarranted fears about the causes of the mutinies.

National Maritime Museum, Greenwich, London, Royal United Service Institution Collection. Object ID: PAG8535.

the officers, and that of the mutineers, which was notably different and reflected their own traditions. Stabilities of form helped to obscure disparities of substance; the result was a hybrid system that subordinated the officers' legitimising theatre of order to mutineer ends. Mutineer power structures were very different to those of officers, but their hegemony continued to be expressed in familiar ways.

\section{MUTINEER EXPRESSIONS OF AUTHORITY}

The orders emanating from the captains' cabins of Queen Charlotte and Sandwich might have been normal, but the source of those orders was anything but. Whereas such orders had previously come from the captain, those of the mutineers originated with a committee of elected delegates drawn from the most skilled and experienced seamen of each ship, who 
could command the respect of their peers. ${ }^{55}$ The mutineer committees of Spithead and the Nore met to draw up rules, formulate policy, conduct negotiations, and liaise between ships. As such, they were crucial to the duration of the mutinies and the maintenance of unity across the fleet. Their new-born egalitarian and discussion-based system was significantly different to the rigid hierarchy of the officers.

These mechanisms of representative democracy, and particularly the use of the term "delegate", led some in government to fear seditious associations between the mutineers, the LCS, UI, or even the French. In response, London magistrate Aaron Graham was sent to Spithead and then, with Daniel Williams, to the Nore to find "evidence or information [...] to show any connection that may have taken place between the mutinies \& the London Corresponding Society" or such groups. ${ }^{56}$ Thompson, Elliott, and Wells have claimed that the course of the mutinies was shaped by links to seditious groups and individuals, but this appears doubtful from contemporary evidence, ${ }^{57}$ and the report by Graham and Williams concluded "that no such connexion or communication ever did exist". ${ }^{8}$ This suggests that we must be sensitive to other possible origins of these practices including sailors' own autonomous tradition of resistance.

Though hierarchically divided by skill, sailors were a clearly defined occupational group with many shared interests, whose survival and success depended on cooperation and coordination. As such, it is not surprising that they repeatedly proved highly effective at organizing protests. The lower decks had hierarchies of their own based on skill and experience, but there were also egalitarian elements. For example, crews were divided into "messes" of six to eight men who cooked and ate together. In most cases, these messes were self-selecting, proud, and tight-knit communities. While sailors tended to mess with men who shared similar jobs, significantly they chose with whom to associate. ${ }^{59}$

It was within character, therefore, for sailors to select who would speak for them during a mutiny. ${ }^{60}$ Furthermore, the collective responsibility inherent in

55. Ibid., p. 44; Manwaring and Dobrée, The Floating Republic, pp. 262-263.

56. TNA HO $42 / 41 / 66$, Home Office Instructions to Graham and Williams, I6 June 1797.

57. E.P. Thompson, The Making of the English Working Class (London, 2013), p. 168; Marianne Elliott, Partners in Revolution: The United Irishmen and France (London, 1982), pp. $135^{-1} 38$; Roger Wells, Insurrection: The British Experience $1795-1803$, pp. 84, I02. I dedicate a chapter of my Ph.D. thesis to the question of involvement by seditious groups and have found no evidence to substantiate such claims.

58. Report of Magistrates Graham and Williams, 24 June 1797 , TNA HO $42 / 4$ I/68, fos 2 I 3-2 I 4. 59. Jones, "Masculinity, Materiality and Space on Board the Royal Navy Ship, 1756-I 8 I 5 ", pp. 85-87, I6I, 365; Michael Lewis, A Social History of the Navy, I793-I8Is (London, I960), pp. $270-27$ I.

60. During several Nore courts martial, defendants claimed they had been forced to serve as delegates against their will: through social pressure, or threat of violence. While these claims should be taken seriously, they were also self-serving in the context of a mutiny trial. 
a committee structure is also reminiscent of established traditions of sailors' protest: notably the "round robin" petition. This involved a statement of grievances with the names of the crew signed in concentric rings so that it would be impossible to identify and punish ringleaders. ${ }^{61}$ Nor does the committee system itself appear to have been without maritime precedent. In I 768 , a strike by merchant sailors paralysed the port of London. A band of forty leading sailors from many ships toured the quays checking terms of service on each ship. Appointed leaders met to draft petitions and demands. ${ }^{62}$ The climax of the strike came when a well-disciplined parade of over I0,000 sailors, with "several ringleaders with Boatswain's whistles interspersed throughout", which "regulated the whole body", marched on Parliament to present their petition. ${ }^{63}$ Organization, collective responsibility, and discipline were established elements of sailors' tradition of protest decades before the 1797 fleet mutinies.

The committee-based power structure of the mutineers was very different to the hierarchical disciplinary regime of the officers. At the Nore, however, the picture was more complicated. There, several mutineers are known to have usurped titles of rank. John Davis, for example, signed orders with the words "John Davis, Captain of the Sandwich" and exercised day-to-day control of the ship. ${ }^{64}$ It should be noted, however, that the roles of such mutineer "captains" were complementary to the committee system, as they administered individual ships while the committee determined overall fleet policy. The legitimising device and theatrical continuity of written orders signed by a mutineer "captain" was combined with a committee-based system of rule drawn, it could be argued, from sailors' traditions of resistance. The two were mutually supporting: the reassuring and unifying theatrical emblems of the rule of officers, and more egalitarian structures of mutineer order. Similarly, leading mutineer George Gainer appropriated the role of an officer when he was observed giving orders, but also the perks attendant on that role when, according to a proud letter home, he persuaded the crew of Sandwich "to pipe the side for me and pay me as much respect as if I was the Admiral of the Ship". ${ }^{65}$ Once again, familiar rituals were used to ornament a radically new regime.

The same could not be said of the adoption by Richard Parker of the title "President" ${ }^{66}$ Unlike the title "captain", there could be no suggestion of

6I. Several examples of surviving round robins can be found in TNA ADMr/5I25, Admiralty Petitions, $1793-98$.

62. Thompson, Customs in Common, p. 76; Richard Sheldon, "The London Sailors' Strike of 1768", in Andrew Charlesworth (ed.), An Atlas of Industrial Protest in Britain, 1750-1990 (London, 1996), pp. I 2-17.

63. Public Advertiser, I 2 May 1768.

64. CMPNM TNA ADMr/5486/ı 2, p. 28; CMPNM TNA ADMr/5486/ı, p. 6; Gill, The Naval Mutinies of 1797 , p. I 24.

65. Helen Watt and Anne Hawkins, Letters of Seamen in the Wars With France (Woodbridge, 20I6), p. 436.

66. NMM HSR $/ Z / 33 / 3$, Nore Letters, 1797 . 
continuity of naval practice here. "President" held connotations of republicanism and particularly of the United States. This might suggest elements of "Atlantic" radicalism of the kind suggested by Frykman but does not necessarily convey revolutionary intent. ${ }^{67}$

On the other hand, the fact that both "Captain" Davis and "President" Parker made use of the written word as an expression of authority suggests a syncretism of usurped naval theatre and mutineer organization. At the Nore, mutineers ordered the captain of Montagu, the Earl of Northesk, to carry a petition and list of demands to London. They issued written instructions which began "You are hereby commanded and directed [...]". ${ }^{68}$ These were the words with which the Admiralty traditionally began their written orders to naval captains. Through their choice of words, the mutineers usurped the jurisdiction of the Admiralty by subverting, not only the medium, but the very words of Admiralty commands. Here, mutineer leaders claimed the role of the supreme naval authority by adopting legitimising cultural practices.

The security and privacy of written correspondence were denied to officers, as demonstrated when Captain Parr of Standard wrote to the Admiralty to explain events on board his ship. The mutineers insisted that he read the letter to the ship's company. The subsequent court martial heard that "Upon Captain Parr's reaching the words 'His Majesty's Ship Standard, under my command"”, the crew laughed and said, "that he could not call the ship under his command". Parr returned to his desk and redrafted the letter to omit "under my command". Only then would the crew permit its postage. ${ }^{69}$ Parr's writing was subjected to public scrutiny and censorship previously unimaginable for correspondence between a captain and his superiors at the Admiralty. By removing the privacy of that correspondence, the leading mutineers had undermined its power. Once aired in public, the captain's writing lost its force, which the mutineers appropriated to themselves.

Sailors were used to many details of their lives being regularly recorded in authoritative official documents: pay books, muster books, and punishments in captains' logs, and Watt and Hawkins have recently shown that literacy rates on the lower decks were higher than has often been assumed..$^{70}$ It appears likely, therefore, that the mutineers were not impressed by the act of writing itself, but by an association between the written word and authority. The signature of a President on some of these orders marked this as a very different regime to its predecessor. The fact, however, that they chose established forms of expressing their command is consistent with a syncretism of traditional naval theatre and rival mutineer power structures drawn from an autonomous sailors' written tradition epitomized by petitions and round robins.

67. Frykman, "Connections between Mutinies in European Navies”, p. I07.

68. CMPNM TNA ADMI $/ 5486 / 3$, p. 29.

69. CMPNM TNA ADMi/5486/I 8, p. 25 .

70. Watt and Hawkins, Letters of Seamen in the Wars With France, pp. 22-23. 
A similar syncretism is visible in the mutineer assumption of punitive power. This was not a purely coercive measure, but also a persuasive one: representative of their new-found hegemony, but also of their responsibility, the justice of their cause, and the virtue of their intentions. The reeved yardropes (nooses) present on most ships undoubtedly exercised a coercive function. ${ }^{71}$ The fact, however, that they were only used to hang effigies challenges their usefulness as a deterrent. While several sailors at the Nore were flogged for lack of dedication to the mutineer cause, more were punished in both mutinies for drunkenness and disrespecting officers. ${ }^{72}$ Both represent continuity rather than change. This was no anarchy or simple coercive regime. Crucially, the new order borrowed the style and methods of the old to claim legitimacy and minimize need for punishment.

There was little violent coercion during the Spithead mutiny. Yardropes were displayed threateningly, but reports that a sailor had been hanged by the mutineers were quickly found to be false. ${ }^{73}$ Reports that four men had been hanged at the Nore were similarly unfounded. ${ }^{74}$ At the Nore several sailors and petty officers were flogged or ducked in the sea for opposing the mutiny, but these were few in number. ${ }^{75}$ Ships that deserted the mutiny were fired upon, but the fact that no fatalities and little damage resulted from this (even when Repulse ran aground during its escape and remained a sitting duck for ninety minutes), suggests that there was no fatal intent. ${ }^{76}$ As under the officers, coercion was just one part of a broader strategy within which violence was a last resort. Familiar theatrical aspects of judicial authority were instead deployed to persuade the crews to remain obedient.

A telling example of mutineer judicial subversion occurred on the Mars at Spithead where delegates met to court martial Samuel Nelson. He was accused of spreading false rumours that the ship's company were unsatisfied with the Admiralty and should defect to France with their ship. The record of this trial shows that the mutineers who sat as judges deliberately adopted the same form and structure as official courts martial. The case for the prosecution was heard first, followed by the defence and character statements. As at official naval courts martial the "judges" were listed, notes taken, witnesses heard and crossexamined. According to regular procedure, the court was cleared while the judges deliberated. The form of the judicial proceedings by the Spithead

71. Pfaff, Hechter and Corcoran, "The Problem of Solidarity in Insurgent Collective Action", p. 256; CMPNM TNA ADMI/5486/10, p. I8; CMPNM TNA ADMI/5486/i, p. 31; though they also reminded the sailors "that mutiny was not anarchy", Gill, The Naval Mutinies of I797, p. 27.

72. CMPNM TNA ADMI/5486/6, p. 3; CMPNM TNA ADMi $/ 5486 / 3$, p. I 2 .

73. Whitehall Evening Post, 20 April 1797.

74. London Evening Post, 3 June 1797.

75. CMPNM TNA ADMI/5486/4, p. 22; CMPNM TNA ADMr/5486/6, pp. 3, 9-10; CMPNM TNA ADMI/5486/25, pp. 22, 39-43, 52, 60; CMP TNA ADM/I/5340, HMS Montagu.

76. Gill, The Naval Mutinies of 1797, p. 235 . 
mutineers can be seen, therefore, as a legitimizing but satirising continuity of official process. The sentence of the Mars mutineers was thoroughly ordinary; the prisoner would "receive at the gangway 24 lashes upon his bare back with a cat of nine tails and then [be] put into irons".

The charge for which Nelson suffered, however, was surely unprecedented in naval law. His seditious utterings, tried by officers, would have earned punishment for "incitement to mutiny". Before the mutineers, he was charged with "betraying the confidence entrusted him by his shipmates" and "breaking the oath of fidelity". ${ }^{77}$ Under normal circumstances, a sailor's duty was to the monarch, so his offences were against the King. In this case, the mutineers considered the legitimate source of sovereignty to rest in the collective will of the ship's company; Nelson's offence was a breach of trust and an affront to the entire crew. As such, Nelson's trial shows an incongruous but effective marriage of official naval process to a different value system. This mutineer trial was reminiscent of the improvised mock-court plays among bored pirates described by Rediker, with the crucial difference that the mutineers were in earnest and their sentence was actually carried out. ${ }^{78}$

Similarly, one of the first acts of the mutineers at both Spithead and the Nore was to compose and circulate written rules. ${ }^{79}$ These functioned like the articles of war, and supplemented rather than replaced those articles. ${ }^{80}$ Before a punishment on board Montagu, prominent mutineer John Durack declared that he "wanted the articles of war for they were going to punish Jack Hanford". ${ }^{8}$ On the one hand, it is not surprising that the mutineers used and mimicked the familiar in seeking to shore up their regime. At the same time, the comparable form and function of the articles of war and the mutineer "laws" might suggest that the mutineers hoped to extend the legitimacy of the former to the latter. This practice contrasts with those of the revolutionary French and Batavian navies. There, the new regimes redrafted the naval legal code along more egalitarian lines, granted trial by jury, and reduced the punitive power of captains. ${ }^{82}$ It is revealing that the British mutineers adopted and supplemented the articles of war rather than replacing them, seemingly accepting their inherent legitimacy.

A more carnivalesque approach to justice was evident at the Nore. Officers ejected from Montagu were subjected to a histrionic form of public humiliation. Five officers were escorted off the ship and into a rowing boat to take them on shore. On the way, however, they were brought alongside Director, where they were obliged to stand up and receive the derision of its crew

77. Trial of Samuel Nelson, NMM MKH/ is.

78. Rediker, Villains of All Nations, pp. I $56-157$.

79. D. Bonner Smith, “The Naval Mutinies of I797”, Mariner's Mirror, 22 (1936), pp. 65-86, 67.

80. CMPNM TNA ADMr/5486/i, p. 26.

8. CMP TNA ADM/ı/5340, HMS Montagu.

82. Frykman, “The Wooden World Turned Upside Down”, pp. I60-161, 227. 
while one was tarred and feathered. All the while, a drummer played "The Rogue's March". ${ }^{83}$ This tune was traditionally heard during punishments, such as when a sailor was flogged round the fleet. ${ }^{84}$ It was, therefore, associated with the shame of punishment and the punitive order of officers. The application of "The Rogue's March" to humiliate officers was a social inversion that effectively tied mutinous crews together in a festival atmosphere of irreverent levity and conveyed the power of the mutineer regime. Here was an opportunity to enjoy the spectacle of their humbled superiors and revel in the reversal of authority. Simultaneously, the use of familiar elements of naval discipline conveyed an impression of continuity and legitimacy for the mutineers as they exercised their control in the same ways as the officers before them. This mimicry employed naval punitive rituals cheek by jowl with new practices; the traditional "Rogue's March" was played not over an official flogging, but a carnivalesque tarring and feathering. Dutch officers were subjected to similar forms of humiliation when the Batavian Cape Squadron surrendered to the British in 1796 , but there the similarities end, as this mutiny was a violently bloody affair, unlike Spithead and the Nore. ${ }^{85}$

The effectiveness of mutineer counter-theatre was observed with concern by naval officers. Perhaps the clearest expression of this unease was a letter sent from the senior officers who composed the panel of judges at the Nore courts martial. They asked the government legal officers if the existing articles of war adequately covered those whose main crime was "assuming the station of officers" ${ }^{86}$ The realization that the officers' theatrical tools of order could prove equally effective when applied to an unlawful and potentially dangerous cause was disquieting and appeared to threaten future naval discipline. Edmund Burke, for example, commented that "as to our Navy, that has already perished with its discipline forever" ${ }^{87}$

Mutineer counter-theatre could be interpreted as an insulting affront to king and officers, and so represented radicalism rather than continuity. This, however, appears irreconcilable with the nature of the mutineer goals (concerned with terms of service, not demanding peace or a change of government), and the respect that was generally shown to officers throughout. Furthermore, at the Nore, the mutineers fired salutes to commemorate the Restoration of Charles II (29 May), and to mark the King's Birthday (4 June). ${ }^{88}$ Here, the

83. CMP TNA ADM/I/5340, HMS Montagu.

84. In this punishment a sailor would receive a set number of lashes alongside each ship of a fleet.

85. Frykman, “The Wooden World Turned Upside Down”, pp. I74-180.

86. Letter from Nore courts martial judges to government law officers, i July I797, NMM $\mathrm{MRK} / \mathrm{IO0} / \mathrm{s} / 8$. The legal officers advised that the existing Articles of War were sufficient to cover such offences.

87. Gilson, Correspondence of Edmund Burke and William Windham, p. 24I. Letter from Burke to Windham, 26 April 1797.

88. See for example Captain's Log of HMS Agamemnon, TNA ADM5 I/ I 194; CMPNM, TNA $\mathrm{ADM} / \mathrm{I} / 5340$, HMS Montagu; Coats and MacDougall, The Naval Mutinies of I797, pp. I69-17I. 
mutineers' used traditional symbolic expressions to communicate their continued loyalty.

It is difficult to gauge the extent to which the mutinies influenced or inspired reformist or revolutionary societies on shore, but two points can be made. Firstly, the Spithead and Nore mutinies resulted in an increased recognition of the significance of oaths. Magistrates Graham and Williams recognized the seriousness with which the sailors obeyed their oaths long after the mutiny was over, and even suggested the introduction of an oath of loyalty for the navy. ${ }^{89}$ Whether these oaths were inspired by illicit groups on shore, or, in turn, inspired such groups to expand their own use of oaths is unclear. Oaths were, however, an established part of the eighteenth-century military code of conduct, particularly among prisoners of war of officer rank. ${ }^{\circ}$ It is possible, therefore, that the mutineer oaths represented another appropriation by sailors of a recognized practice among their superiors. What is known is that Parliament feared one or more of these possibilities sufficiently to abolish "Unlawful Oaths" soon after the mutinies..$^{9 \mathrm{I}}$

Secondly, Marianne Elliott argued that the fleet mutinies awoke the UI to the possibility of infiltrating and disabling the navy. Elliott concluded that "intermittent United participation in other mutinies over the next few years suggest a continuous policy of United infiltration long after the Nore and Spithead mutinies had collapsed"..$^{2}$ The mutinies might, therefore, have inspired an opportunistic and imitative (though unsuccessful) new strategy among seditious societies on shore.

\section{CONCLUSION}

A distinction has often been drawn between the respectable Spithead mutiny and the "more serious" or "uglier" Nore mutiny. ${ }^{93}$ These views are substantiated by some actions of the Nore mutineers, which went far beyond those of their predecessors at Spithead, such as blockading the Thames, humiliating the officers of the Montagu, and firing upon Royal Navy ships. However, this interpretation understates the continuities of counter-theatrical behaviour across the two mutinies: the use of spaces of authority, the creation of written rules, regular cheering, and disciplinary procedures. In addition, several

89. Report of Magistrates Mr Graham and Mr Williams, 24 June I797, TNA HO42/4I/68, fos 2I3-2I4.

90. Renaud Morieux, "French Prisoners of War, Conflicts of Honour, and Social Inversions in England, 1744-1783", The Historical Journal, 56 (2013), pp. 55-88, 62-63.

91. Unlawful Oaths Act 1797 (37 Geo. III).

92. Elliott, Partners in Revolution: The United Irishmen and France, pp. 143-44.

93. Peter Hore, The Habit of Victory: The Story of the Royal Navy, I 545 to 1945 (London, 2005),

p. I42; Roger Knight, Britain Against Napoleon: The Organization of Victory, I793-I8IS

(London, 2013), p. 89. 
elements of their new regimes drew on the same sailors' traditions of resistance, such as the committee structure and use of petitions. Apart from the fact that the Nore mutineers did not accept the Spithead settlement but held out for greater concessions, there was little to separate the beginnings of the two mutinies.

Therefore, far from being used as evidence of a greater nascent radicalism among the Nore mutineers, their increasingly drastic actions could, with equal plausibility, suggest growing desperation and frustration at the lack of progress. Whereas the Spithead mutiny fell into a cycle of negotiation and compromise, the Nore degenerated into a cycle of distrust and escalation. This interpretation would explain how the initial practical similarities between the two mutinies: their use of a hybrid system combining the usurpation of established facets of naval order and new systems of power, were taken to increasingly desperate extents at the Nore. Faced with Admiralty intransigence, the Nore mutineers exceeded the restraint of the Spithead mutiny; the committee was supplemented by a "President", officers were not just confined but humiliated, and the Thames was blockaded in order to acquire much-needed supplies. While one must be sensitive to the distinct paths and denouements taken by the Spithead and Nore mutinies, studying the two together is justified by the desire to understand their similarities and differences.

The social inversions achieved during the Spithead and Nore mutinies should not be mistaken for anarchy. The mutineers did not remove the images of naval order; they used them, supplemented by others of their own, in support of their new regime through the creation of unity and rule by theatre. In this way the mutineers diverged from their counterparts in the French and Dutch navies, who, reflecting their revolutionary context, were more willing to fully replace the traditional markers of naval authority. Coercion was present during the mutinies, but it was not sufficient to explain their duration.

As the mutineers used rather than subverted the symbols of naval order, the determination of the naval authorities to punish this behaviour might appear contradictory, but this is based on a false distinction. For the mutineers to use these instruments of naval authority was to subvert them, as they were not theirs to use. Though the threat of coercive violence was omnipresent, the rule of officers generally rested on ritual, ceremonial, and symbols. The realization that sailors had not only recognized these strategies but used them for their own ends, even if predominantly marked by moderation and continuity, was dangerous and discomforting. If a magician reveals his tricks, the magic is lost. When the mutineers usurped the methods of naval authority, some, with Burke, wondered if the spell of naval discipline was broken forever.

The forms of counter-theatre employed by the mutineers offer direct parallels to similar practices during crowd action on shore. Referring to protests on land in eighteenth-century Britain, Brewer argued that crowds used symbols, flags, and music (all present in mutineer parades at Sheerness) to support their 
cause, and that these represented a "'belief system' made concrete" ${ }^{94}$ Often, symbols of authority were repurposed to aid the protesters. It was common, for example, for crowds to "execute" effigies while observing "the proper forms and customs of a public execution". ${ }^{95}$ These effigies were sometimes incarcerated in the local jail overnight and then paraded to the usual place of execution in the same wagon used to convey condemned criminals. These wagons were also occasionally employed by crowds to evict unpopular local officials from a parish, thereby emphasising the public disdain for the individual concerned, and their consequent ostracism from the community. ${ }^{96}$ The similarities are clear between these practices and the expulsion of officers from Montag $u$ via small boat while the Rogue's March was played. The officers were conveyed away in the same craft and to the same tune as convicted criminals going to be flogged round the fleet.

At the same time, the mutineers did not simply step straight into the vacated shoes of their officers. Instead they complemented their own new power structure using several familiar theatrical representations of naval discipline. The result was a hybrid marriage of lower-deck traditions of organization to the reassuring, legitimising, and unifying continuity of established elements of naval order. This composite strategy, with mutineer counter-theatre at its heart, was instrumental to the scale and duration of the 1797 fleet mutinies, and to their overwhelming reliance on persuasion rather than coercion.

\section{TRANSLATED ABSTRACTS \\ FRENCH - GERMAN - SPANISH}

Callum Easton. Contre-théâtre pendant les mutineries de flottes en 1797.

Résumé: Au printemps de I797, alors que l'invasion française semblait probable, les mutins du Spithead et du Nore immobilisèrent successivement les deux flottes de la Royale Navy chargées de la défense territoriale. Les mutins du Spithead obtinrent une meilleure solde et de plus grandes rations alimentaires pour tous les marins de la Royal Navy et une amnistie générale pour eux-mêmes. La mutinerie du Nore se conclut par l'effondrement, les tribunaux militaires et l'exécution d'environ vingt-huit mutins proéminents. Quant à leur ampleur et leur danger potentiel, ces mutineries de flottes furent parmi les plus graves manifestations de résistance collective dans le RoyaumeUni du dix-huitième siècle. Du point de vue de la complexité, elles dépassèrent de loin les mutineries de navire unique telles que celles du Bounty ou de l'Hermione. Les mutins subvertirent délibérément les symboles de la règle légitime des officiers et

94. Brewer, Party Ideology and Popular Politics, p. I 82.

95. Ibid., p. I 84 .

96. Carl J. Griffin, The Rural War: Captain Swing and the Politics of Protest (Manchester, 2012); p. 174 . 
les déployèrent pour soutenir leur propre régime rival. Ce "contre-théâtre" permit aux chefs des mutins de perpétuer leur règle avec un recours minimum à la coercition, en combinant les symboles familiers de l'ordre naval, les nouvelles structures de pouvoir des mutins et les traditions de résistance de marins. En tant que telles, les mutineries s'inscrivent dans des littératures plus vastes: les récits de l'âge des révolutions, l'Atlantique révolutionnaire et les récits de protestation et de résistance populaires.

Traduction: Christine Plard

\section{Callum Easton. Gegentheater in den Meutereien von 1797.}

Im Frühjahr 1797, als eine französische Invasion für wahrscheinlich gehalten wurde, legten die Meutereien auf der Spithead und der Nore nacheinander jene beiden Flotten der Royal Navy lahm, die für die Landesverteidigung zuständig waren. Die Meuterer auf der Spithead konnten für sämtliche Seeleute der Royal Navy eine bessere Bezahlung sowie großzügigere Lebensmittelrationen, für sich selbst eine Generalamnestie durchsetzen. Die Meuterei auf der Nore endete mit ihrem Zusammenbruch, Standgerichten sowie der Hinrichtung von ungefähr 28 prominenten Meuterern. Hinsichtlich ihres Ausmaßes und Gefahrenpotenzials zählen diese beiden flottenweiten Meutereien zu den gravierendsten Fällen kollektiven Widerstands, die im Großbritannien des i8. Jahrhunderts $\mathrm{zu}$ verzeichnen waren. Ihre Komplexität überstieg bei Weitem die der auf einzelnen Schiffen, etwa der Bounty oder der Hermione ausgebrochenen Meutereien. Die Meuterer unterzogen die Symbole legitimer Offiziersautorität einer planvollen Subversion und gebrauchten diese Symbole zur Stützung ihres eigenen, rivalisierenden Regimes. "Gegentheater" erlaubte es den Anführern der Meuterei, ihre Herrschaft unter minimalem Einsatz von Zwang zu verstetigen, indem sie vertraute Symbole der Schiffsordnung mit neuen Machtstrukturen unter den Meuterern sowie mit den Widerstandstraditionen der See kombinierten. Insofern sind diese Meutereien für mehr als nur einen Forschungsbereich relevant: Sie berühren die Historiographie des Zeitalters der Revolutionen, des revolutionären Atlantiks, aber auch die volkstümlicher Protest- und Widerstandsformen.

\section{Übersetzung: Max Henninger}

\section{Callum Easton. Contra-teatro durante los motines de la flota de 1797.}

En la primavera de 1797, cuando la invasión francesa apenas había dado comienzo, los motines de Spithead y Nore inmovilizaron de forma sucesiva de las dos flotas de la Royal Navy responsables de la defensa del territorio. Los amotinados de Spithead consiguieron un aumento de la paga y mejores raciones de comida para todos los marineros de la Royal Navy, además del perdón general para todos ellos. Los participantes en el motín de Nore acabaron derrotados, sometidos al proceso de una corte marcial que acabó con la ejecución de aproximadamente veintiocho de los amotinados más prominentes. En razón de sus dimensiones y de su potencial amenaza, estos motines en la flota losa podemos situar entre las más serias manifestaciones de resistencia colectiva en el siglo XVIII en Gran Bretaña. Por su complejidad, se trató de motines que fueron más allá de la sola actividad de una nave, como los del Bounty o el Hermoine. Los 
amotinados subvirtieron de forma deliberada símbolos del mando legítimo de los oficiales y los desplegaron en apoyo de su propio orden alternativo. El 'contra-teatro' permitió a los líderes del motín perpetuar su mando recurriendo de forma muy esporádica a la coerción combinando los símbolos habituales del mando naval, las nuevas estructuras de poder de los amotinados y las tradiciones marineras de resistencia. De esta forma los motines nos hablan de literaturas más amplias: de historias de la era de las revoluciones, del Atlántico revolucionario y de historias de la protesta popular y la resistencia.

Traducción: Vicent Sanz Rozalén 